\title{
Evaluation of Cadmium Bioaccumulation-Related Physiological Effects in Salvinia biloba: An Insight towards Its Use as Pollutant Bioindicator in Water Reservoirs
}

\author{
Julia Emiliani 1, $+\ddagger$, Wendi G. Llatance Oyarce ${ }^{2, \ddagger}$, Lucas M. Salvatierra ${ }^{1,3}\left(\mathbb{D}\right.$, Luís A. B. Novo ${ }^{4, *(D)}$ \\ and Leonardo M. Pérez ${ }^{1,3, *(\mathbb{D})}$
}

Citation: Emiliani, J.; Oyarce, W.G.L.; Salvatierra, L.M.; Novo, L.A.B.; Pérez, L.M. Evaluation of Cadmium Bioaccumulation-Related Physiological Effects in Salvinia biloba: An Insight towards Its Use as Pollutant Bioindicator in Water Reservoirs. Plants 2021, 10, 2679. https://doi.org/10.3390/ plants10122679

Academic Editors: Erica Lumini, Magda Pál and Luca Forti

Received: 2 October 2021

Accepted: 30 November 2021

Published: 6 December 2021

Publisher's Note: MDPI stays neutral with regard to jurisdictional claims in published maps and institutional affiliations.

Copyright: (c) 2021 by the authors. Licensee MDPI, Basel, Switzerland. This article is an open access article distributed under the terms and conditions of the Creative Commons Attribution (CC BY) license (https:// creativecommons.org/licenses/by/ $4.0 /)$.
1 Grupo de Biotecnología de Materiales y Medioambiente (Bio\&TecMA), Instituto de Investigaciones en Ingeniería Ambiental, Química y Biotecnología Aplicada (INGEBIO-UCA), Facultad de Química e Ingeniería del Rosario, Pontificia Universidad Católica Argentina (UCA), Av. Pellegrini 3314, Rosario S2002QEO, Santa Fe, Argentina; juliaemiliani@uca.edu.ar or jemiliani@cbm.csic.es (J.E.); lucas_salvatierra@uca.edu.ar (L.M.S.); leonardoperez@uca.edu.ar (L.M.P.)

2 Centro de Análisis Espectrofotométrico, Universidad Nacional de Jaén, Jirón Cuzco 250, Jaén 06801, Peru; wendi.llatance@unas.edu.pe

3 National Council for Scientific and Technical Research (CONICET), Ministry of Science, Technology and Productive Innovation, Godoy Cruz 2290, Buenos Aires C1425FQB, Argentina

4 Scotland's Rural College, West Mains Road, The King's Buildings, Edinburgh EH9 3JG, UK

* Correspondence: luis.novo@sruc.ac.uk (L.A.B.N.); perez@inv.rosario-conicet.gov.ar (L.M.P.); Tel.: +441-316-519-339 (L.A.B.N.); +549-341-421-130 (L.M.P.)

† Current Address: Centro de Biología Molecular Severo Ochoa (CBMSO), CSIC-UAM, C/Nicolás Cabrera 1, Cantoblanco, 28049 Madrid, Spain.

$\ddagger$ Both authors contributed equally to this work.

\begin{abstract}
Free-living macrophytes play an important role in the health of aquatic ecosystems. Therefore, the use of aquatic plants as metal biomonitors may be a suitable tool for the management of freshwater reservoirs. Hence, in this study, we assessed the effects of cadmium (Cd) in Salvinia biloba specimens collected from the Middle Paraná River during a 10-day experiment employing artificially contaminated water $(100 \mu \mathrm{M}$ Cd). S. biloba demonstrated a great ability for Cd bioaccumulation in both the root-like modified fronds (named "roots") and the aerial leaf-like fronds (named "leaves") of the plants. Additionally, Cd toxicity was determined by the quantification of photosynthetic pigments (chlorophylls $a$ and $b$, and carotenoids), flavonoids, and soluble carbohydrate contents in S. biloba over time $(1,3,5,7$, and 10 days). In general, deterioration was more pronounced in leaves than in roots, suggesting a greater implication of the former in long-term Cd sequestration in S. biloba. Deleterious effects in the appraised parameters were well correlated with the total amount of $\mathrm{Cd}$ accumulated in the leaves, and with the qualitative changes observed in the plants' phenotype during the 10-day metal exposure assay. The flavonoids and carotenoids in leaves were highly affected by low $\mathrm{Cd}$ levels followed by root carbohydrates. In contrast, chlorophylls and root flavonoids were the least impacted physiological parameters. Therefore, our results demonstrate that S. biloba displays dissimilar organ-linked physiological responses to counteract $\mathrm{Cd}$ phytotoxicity and that these responses are also time-dependent. Though further research is needed, our work suggests that easy-handled physiological data obtained from autochthonous free-floating $S$. biloba specimens may be used as a valuable tool for metal-polluted water biomonitoring.
\end{abstract}

Keywords: metal-polluted waters; cadmium; biomonitoring; autochthonous macrophyte species; Salvinia biloba

\section{Introduction}

Free-floating macrophytes (i.e., hydrophytes) are macroscopic aquatic plants that play an important role in aquatic ecosystem health. These organisms are key components in natural wetlands and can serve as bioindicators of a variety of ecosystem stressors 
such as nutrient runoff, changes in hydrologic regime, and exotic species invasion. In addition, macrophytes may be also indicative of water contamination caused by human activities such as industrial, agricultural, and mining exploitation [1-4]. Therefore, the use of macrophytes as biomonitors of stream health should be considered as a useful tool for the management of aquatic ecosystems. However, bioindicators estimating the pollutants affecting the biota in an ecosystem are often purely qualitative in nature.

During the last two decades, free-floating macrophytes have been extensively studied in relation to its growth, metabolic response, and phytoremediation capacity towards several environmental contaminants, especially heavy metals [5-11]. Moreover, the phytotoxic effects of metal contaminants on aquatic vegetation have been addressed with regard to changes in plant phenotype and population, and/or the impact on different physiological parameters due to metal stress (e.g., photosynthetic pigment content, antioxidant enzyme activities, etc.). In fact, when growing in contaminated sites, macrophytes may develop differential phytopathological alterations in different organs (i.e., submerged roots and aerial leaves) showing a high morphological and metabolic plasticity [12-19]. Hence, in macrophyte ecotoxicological studies, it seems appropriate to evaluate metal-induced changes on different biological parameters in both plant organs since these results may differ and, in this way, new insights for their use as pollutant bioindicators could be provided. However, limited information is available in the scientific literature about the use of macrophytes as biomonitoring agents for heavy metal-polluted aquatic environments from a physiological perspective $[4,5,17]$. On the other hand, the use of aquatic plants for phytoremediation of metal-polluted water and wastewater has been comprehensively demonstrated as a highly efficient and cost-effective method for toxic metal elimination [5-19]. Thus, local macrophyte species with an elevated biomass production rate enable more sustainable and economically viable phytoremediation strategies, especially in areas where communities have limited financial resources $[12,13,19]$.

In Argentina, the ecosystem surrounding the Middle Paraná River is well characterized by an extensive wetland area with copious and diverse aquatic vegetation due to the temperature and light favorable regime of this region [20,21]. Different macrophytes belonging to the Salvinia family obtained from Paraná River floodplain have been studied for metal removal from polluted environments. In particular, Salvinia biloba has showed a high growth rate, great capacity to survive under adverse environmental conditions, and proper heavy metal removal capacity, including cadmium $(\mathrm{Cd})$, lead $(\mathrm{Pb})$, copper $(\mathrm{Cu})$, zinc $(\mathrm{Zn})$, nickel $(\mathrm{Ni})$, and chromium $(\mathrm{Cr})[6,12,13,18,19]$.

Globally, $\mathrm{Cd}$ is one of the most concerning water pollutants. Although its toxicity is a highly researched topic, $\mathrm{Cd}$ pollution is far from being under control [22,23]. Common sources of $\mathrm{Cd}$ include wastes from mining and metallurgical operations, electroplating industries, Cd-based batteries, and runoff water from agriculture soils impacted with $\mathrm{Cd}$ containing fertilizers, among others. In addition, a large amount of $\mathrm{Cd}$ is naturally released into rivers through the weathering of rocks [22]. Cadmium is highly toxic to the aquatic ecosystem, including fish, plants, and other organisms [24,25]. Moreover, long-term human exposure to $\mathrm{Cd}$ has been associated with kidney and chronic liver dysfunction and with an increased risk of prostate, lung, endometrium, bladder, and breast cancer [22,23,26]. In fact, this element is classified as a Group 1 human carcinogen, and it is also currently listed by the World Health Organization (WHO) as 1 of the 10 chemicals of major public concern [27]. Thus, $\mathrm{Cd}$ is considered a priority water pollutant from a monitoring perspective by most countries and international organizations.

To the best of our knowledge, there are no studies describing the biomonitoring ability of native S. biloba specimens exposed to Cd. Furthermore, there is limited information on the time-dependent effects of $\mathrm{Cd}$ on $S$. biloba physiological parameters [12]. Therefore, the aim of the present study was to evaluate the metal bioaccumulation capacity of autochthonous free-floating $S$. biloba specimens exposed to Cd-polluted water over a 10-day period. Additionally, chlorophylls ( $a$ and $b$ ), carotenoids, flavonoids, and soluble carbohydrate contents were also assessed in order to link easy-acquired physiological 
information with the potential role of these locally available macrophytes as biomonitoring agents for $\mathrm{Cd}$ water pollution.

\section{Materials and Methods}

\subsection{Plant Collection and Characterization}

Naturally-occurring S. biloba specimens were collected from an uncontaminated shallow lake located in a floodplain at the Middle Paraná River in front of Rosario city $\left(32^{\circ} 52^{\prime} 35^{\prime \prime} \mathrm{S} ; 60^{\circ} 40^{\prime} 33^{\prime \prime} \mathrm{W}\right.$, Santa Fe, Argentina), a natural wetland environment in which S. biloba develops conspicuously $[12,13,20]$. During manually collection, the plants were stored at ambient temperature in plastic recipients containing river water until they were transported to the laboratory. Once at the lab, the macrophytes were acclimated during 15 days at controlled room temperature $\left(24 \pm 2{ }^{\circ} \mathrm{C}\right)$ under natural light in a hydroponic system (20 L glass aquaria) containing a combination (50:50) of tap water and river water. Taxonomic classification of the collected macrophytes was performed based on morphological characteristics [13].

\subsection{Cd Bioaccumulation Studies}

Plants with uniform size and without any visual signs of deterioration (i.e., loss of turgor, defined chlorosis and/or necrosis areas on plant leaves, etc.) were chosen for further experimental purposes. The selected S. biloba specimens were placed (10.0 g wet basis) in beaker glass $(600 \mathrm{~mL})$ containing $400 \mathrm{~mL}$ of $100 \mu \mathrm{M} \mathrm{Cd}$ solution (i.e., $11.2 \mathrm{mgCd} / \mathrm{L}$ ), prepared by diluting a commercial standard Cd solution $(1000 \mathrm{mg} / \mathrm{L}$, SCP Science, Quebec, Canada) in deionized water. The experiments were carried out at $24 \pm 2{ }^{\circ} \mathrm{C}$ under artificial light (Osram Dulux L HE, München, Germany) with dark/light cycles of $12 \mathrm{~h}[12,13,20]$. The $\mathrm{pH}$ of the solution ( $\mathrm{pH}$ 6.0-7.0) was assessed during all the assays using an AD1030 digital pH-meter (Adwa, Nușfalău, Romania) in order to avoid possible $\mathrm{Cd}(\mathrm{OH})_{2}$ precipitation. Three experimental units $(n=3)$ were used as replicates for each exposure time $(0,1,3,5,7$, and 10 days) and the data were reported as mean value \pm standard error (S.E.). At the end of each exposure time, total biomass was collected and gently washed with deionized water. Later, plant biomass was washed with $400 \mathrm{~mL}$ of $1.7 \mathrm{mM}$ EDTA solution (concentration equivalent to a molar ratio EDTA/Cd $\geq 17$ ) for 60 min under gentle orbital agitation (80 rpm) to eliminate $\mathrm{Cd}$ adsorbed on the plant surface. Then, the EDTA-washed biomass was rinsed with deionized water and separated in submerged root-like modified fronds (named "roots"), and aerial leaf-like fronds (named "leaves"), for further physiological parameter analysis (see Section 2.3). Subsequently, another portion of the washed biomass was dried at $90^{\circ} \mathrm{C}$ to constant weight. Finally, $50.0 \mathrm{mg}$ of dried biomass were treated with $1.0 \mathrm{~mL} 65 \% \mathrm{HNO}_{3}$ analytical grade (Cicarelli, Santa Fe, Argentina) and heated at $120^{\circ} \mathrm{C}$ in a digestion system for $2 \mathrm{~h}$. Aliquots of digested samples were accordingly diluted with acidic water $(0.15 \% v / v$ HNO3, Cicarelli, San Lorenzo, Argentina) in glass calibrated containers to quantify the amount of $\mathrm{Cd}$ accumulated in plant tissues by atomic absorption using a Varian AA240FS spectrophotometer (Varian Inc., Palo Alto, CA, USA). For calibration purposes, standard solutions of $\mathrm{Cd}(0.30,0.60,1.0,2.0,2.5$, and $3.0 \mathrm{mg} / \mathrm{L})$ were prepared by diluting a commercial standard solution (1000 $\mathrm{mgCd} / \mathrm{L}$, SCP Science, Quebec, Canada) with the necessary volume of acidified water $\left(0.15 \% v / v \mathrm{HNO}_{3}\right.$; Cicarelli, San Lorenzo, Argentina) in glass calibrated containers, as recommended by the Varian AA240FS operational manual. All calibration procedures showed reproducible linear relationships $\left(R^{2}>0.98\right)$.

\subsection{Physiological Parameters}

\subsubsection{Quantification of Photosynthetic Pigments}

Photosynthetic pigments (chlorophylls and carotenoids) were quantified from $50.0 \mathrm{mg}$ $(n=3)$ of fresh biomass (FW) added with $96 \%(v / v)$ ethanol $(1.0 \mathrm{~mL})$ and incubated for $24 \mathrm{~h}$ in darkness at $4{ }^{\circ} \mathrm{C}$. The extract was centrifuged $(10 \mathrm{~min}, 4500 \times \mathrm{g})$ and the absorbance of the supernatant was measured at 480, 649, and $665 \mathrm{~nm}$ by using a Lambda 25 UV-vis spectrophotometer (Perkin Elmer, Boston, MA, USA). Contents of chlorophylls ( $a$ and $b$ ) 
and carotenoids (carotenes and xanthophylls) were expressed as $\mu \mathrm{g} / \mathrm{g}$ (FW) and calculated according to [28]. Data were reported as the mean value \pm standard error (S.E.) from three biological replicates $(n=3)$.

\subsubsection{Flavonoid Determination}

The content of flavonoids was assessed as described in [15]. Briefly, $50.0 \mathrm{mg}(n=3)$ of fresh biomass (FW) were extracted for $8 \mathrm{~h}$ with $0.6 \mathrm{~mL}$ of acidic methanol $(1 \% \mathrm{v} / \mathrm{v} \mathrm{HCl}$ in methanol), followed by a second extraction with $1.2 \mathrm{~mL}$ of chloroform and $0.6 \mathrm{~mL}$ of distilled water. After vortexing, the extracts were centrifuged ( $5 \mathrm{~min}, 4500 \times \mathrm{g}$ ) and the absorbance of the supernatant was measured at $330 \mathrm{~nm}$ using a UV-vis Lambda 25 spectrophotometer (Perkin Elmer, Boston, MA, USA). Finally, the flavonoid content was expressed as absorbance units $\left(\mathrm{A}_{330}\right)$ per gram of FW [12,13,15-17]. Data were reported as the mean value \pm standard error (S.E.) from three biological replicates $(n=3)$.

\subsubsection{Soluble Carbohydrates}

The content of soluble carbohydrates was determined according to [29]. Briefly, $100 \mathrm{mg}$ $(n=3)$ of fresh biomass (FW) were mixed with $80 \%(v / v)$ methanol $(2.0 \mathrm{~mL})$ and heated $\left(70{ }^{\circ} \mathrm{C}, 30 \mathrm{~min}\right)$. After being cooled, $1.0 \mathrm{~mL}$ of the extract was added with $6.0 \mathrm{~mL}$ of an acidic solution of $5 \%(v / v)$ phenol (Sigma-Aldrich, St. Louis, MO, USA). Finally, the mixtures were incubated at room temperature for $60 \mathrm{~min}$, and the absorbance of the solution was measured at $490 \mathrm{~nm}$ using a UV-vis Lambda 25 spectrophotometer (Perkin Elmer, Boston, MA, USA) [15]. The concentration of soluble carbohydrates was expressed as $\mathrm{mg} / \mathrm{g}$ FW using Glucose (50 mg) as the standard (Sigma-Aldrich, St. Louis, MO, USA) [13]. Data were reported as the mean value \pm standard error (S.E.) from three biological replicates $(n=3)$.

\subsection{Statistical Analysis}

Statistical analyses were performed using the SigmaStat 3.5 program (Systat Software Inc., San Jose, CA, USA). Following the assessment of data normality and homogeneity of variances, the ANOVA test was used to compare the collected data between control and Cd-treated samples during the 10-day assay. Tukey's post-hoc test was applied when the differences in the measured values were different $(p<0.05)$. Pearson correlation coefficients were computed in the R ver. 4.1.0 (R Foundation for Statistical Computing, Vienna, Austria) environment [30] to appraise the relationship between parameters.

\section{Results and Discussion}

\subsection{Cd Bioaccumulation}

Metal phytoremediation in S. biloba can be explained by a combination of several coordinated mechanisms involving the metal union to the plant biomass, the metal translocation through the cell wall, and finally the metal sequestration, transport, and storage into different cell compartments. In a recent work, we have demonstrated that Cd uptake within S. biloba biomass was the main removal mechanism used by these macrophytes to remove the metal from the water column [12]. In this study, we evaluate the pattern of $\mathrm{Cd}$ bioaccumulation in the root-like modified fronds (named "roots") and the aerial leaf-like fronds (named "leaves") of naturally occurring S. biloba specimens during 10 days of plant exposure to water artificially contaminated with $100 \mu \mathrm{M} \mathrm{Cd}$.

Figure 1 shows the mean value of metal bioaccumulated $(\mathrm{mg} / \mathrm{g})$ in separate roots and leaves of Cd-treated plants after 1, 3, 5, 7, and 10 days of metal exposure for three biological replicates. As can be seen, $\mathrm{Cd}$ bioaccumulation in both organs was positively affected by the exposure time increase (Figure 1). During the first $72 \mathrm{~h}, \mathrm{~S}$. biloba showed a greater capacity $(p<0.05)$ to incorporate Cd within plant roots (from $720 \pm 76 \mu \mathrm{g} / \mathrm{g}$ at $24 \mathrm{~h}$ to $1650 \pm 112 \mu \mathrm{g} / \mathrm{g}$ at $72 \mathrm{~h}$ ) regarding the amount of the metal incorporated into the leaves (from $531 \pm 118 \mu \mathrm{g} / \mathrm{g}$ at $24 \mathrm{~h}$ to $891 \pm 131 \mu \mathrm{g} / \mathrm{g}$ at $72 \mathrm{~h}$ ). 


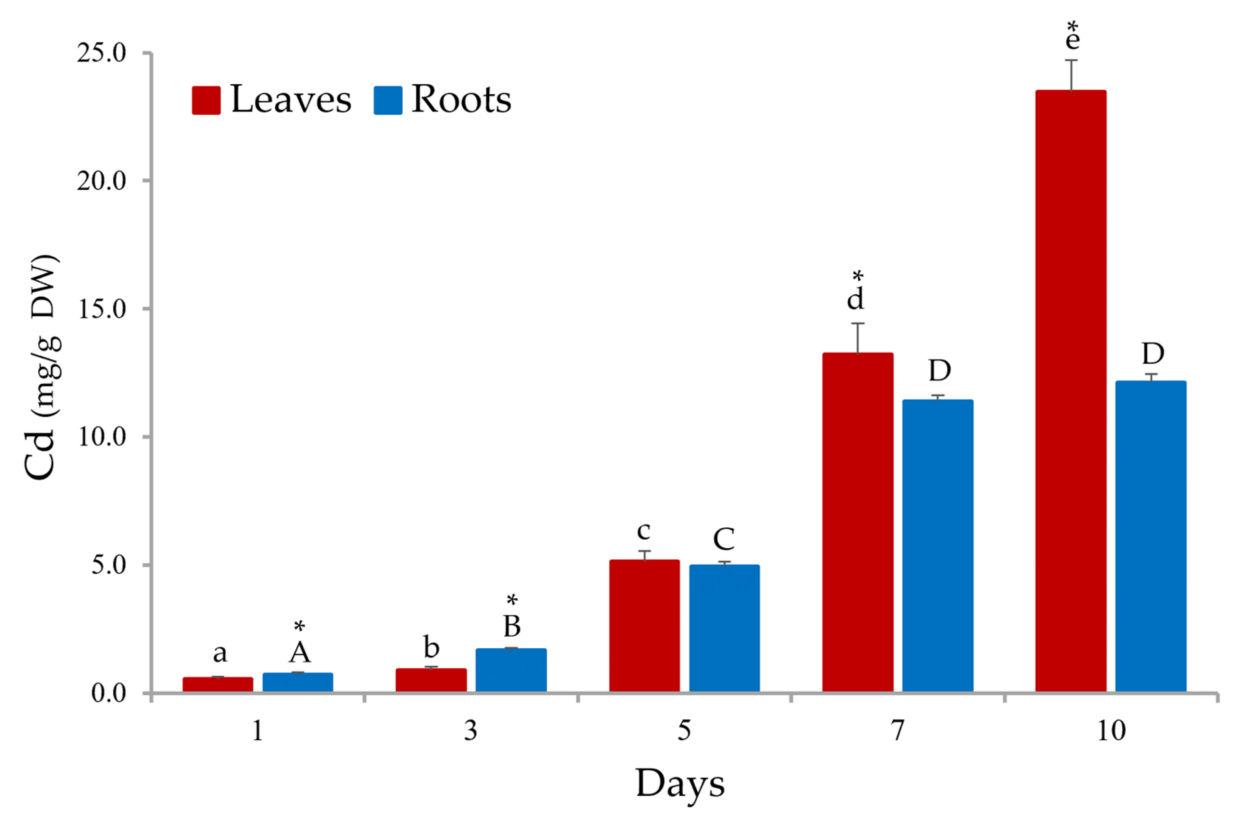

Figure 1. Metal bioaccumulation in roots and leaves of S. biloba specimens exposed to water contaminated with $100 \mu \mathrm{M} C d$ for 10 days. Different letters represent significant differences $(p<0.05)$ between $\mathrm{Cd}$ accumulated in roots (uppercase letters) or leaves (lowercase letters) at increasing exposure time. * Indicates significant differences $(p<0.05)$ between $\mathrm{Cd}$ accumulated in roots and leaves of S. biloba at the same exposure time. Data are reported as the mean value \pm standard error (S.E.) from three biological replicates $(n=3)$.

This behavior is in agreement with our previous report, proving that $S$. biloba uses different mechanisms for divalent cation removal from polluted waters [12]; where the fastest component of $\mathrm{Cd}$ uptake by these plants is surface adsorption followed by metal bioaccumulation in the submerged root-like modified fronds. This phenomenon occurs through the combination of physicochemical and biological processes including ionic bonds, chemical chelation, and cationic exchange during the adsorption phase, followed by a translocation step involving the action of transmembrane proteins and ionic channels $[6,12,18,19,31,32]$. Estrella-Gómez et al. [33] demonstrated the relationship between metal bioaccumulation and the activation of metal sequestration mechanisms mediated by phytochelatins in the roots of Salvinia minima exposed to $\mathrm{Pb}$. Metal sequestration by cysteine- and glutamic acid-rich peptides such as glutathione, phytochelatins, and metallothioneins are some of the best well-known mechanisms of metal detoxification in plants. These proteins have the ability to bind toxic metals, forming complexes that are later stored in vacuoles and chloroplasts, thus reducing the deleterious effect of toxic metals to cells $[34,35]$. Hence, it may be expected that most Salvinia species share similar chelating mechanisms involving phytochelatin and/or metallothionein expression during Cd uptake [36,37]. In addition, Olguín et al. [32] have suggested that calcium channels may also be involved in the intracellular accumulation of divalent metals in Salvinia species. However, more evidence is needed to support this hypothesis.

Metal translocation to the aerial parts of the plant (i.e., leaves) is a much slower phase of the Cd removal mechanism used by S. biloba. During the first three days of metal exposure, the amount of $\mathrm{Cd}$ incorporated in plant leaves was significantly $(p<0.05)$ lower $(891 \pm 131 \mu \mathrm{g} / \mathrm{g})$ than the metal concentration found in plant roots $(1650 \pm 112 \mu \mathrm{g} / \mathrm{g})$. However, from day 5 onwards, the amount of Cd bioaccumulated in S. biloba leaves was highly increased (Figure 1), doubling the amount of the metal accumulated by the plant roots at the end of the assay $(23,450 \pm 1250 \mu \mathrm{g} / \mathrm{g}$ in leaves vs. $12,100 \pm 340 \mu \mathrm{g} / \mathrm{g}$ in roots). This observation matches our previous results using autochthonous free-floating S. biloba specimens exposure to water contaminated with $100 \mu \mathrm{M} \mathrm{Pb}$ [38]. In such work, we demonstrated that after 30 days of metal exposure the amount of $\mathrm{Pb}$ accumulated 
in S. biloba biomass increased with the concomitant decrease in the total amount of $\mathrm{Pb}$ adsorbed onto plant roots. The finding suggests that this behavior involves the metal translocation/transport from roots into leaves by the presence of both transmembrane and intracellular metal-carrier proteins as part of a metal-tolerance mechanism developed by the plants [39].

The bioconcentration factor $(\mathrm{BCF})$ can be employed as a gauge for metal-uptake efficiency in different macrophytes commonly used in phytoremediation trials [19]. In general, high BCF values denote high metal cumulative loads in the plant biomass for different metals, which can be desired for vegetal species selection in terms of designing a bio-based system for metal-polluted water treatment. Interestingly, as it can be inferred from Figure 1, BCF values significantly increase with exposure time in both plant organs, suggesting a high $\mathrm{Cd}$ cumulative capacity for $\mathrm{S}$. biloba. However, the different physiological needs of a plant, the metal toxicity and its uptake kinetics could directly or indirectly affect the accumulative bioprocesses for a particular metal ion in different macrophytes species.

\subsection{Phenotypic Evaluation of Cd Phytotoxicity in S. biloba}

Cadmium is a non-essential element that negatively affects plant growth and development. It has been reported that aquatic plants belonging to Salvinia sp. and exposed to toxic metals show typical symptoms, such as leaf chlorosis/necrosis, the appearance of a brownish-red coloration on the leaf surface, or a reduced total biomass yield $[6,12,13,17]$. Moreover, a possible reason for $\mathrm{Cd}$ toxicity is its chemical similarity to ferrous ion $\left(\mathrm{Fe}^{2+}\right)$, which can be replaced in Cd-exposed plants, thus affecting many vital physiological processes and producing several morphological and structural damages [17].

In the present study, the phytotoxic effects observed in the biomass of naturally occurring $S$. biloba specimens over 10 days of metal exposure to water contaminated with $100 \mu \mathrm{M}$ Cd are shown in Figure 2. A gradual response of S. biloba to Cd phytotoxicity was observed, mostly evidenced by a marked leaf chlorosis (i.e., green chlorophylls change towards darker areas), alterations in the size and the shape of the leaves, and the emergence of signs of necrosis (cell death) in both the juvenile fronds and in the most developed ones. In fact, the occurrence of the necrotized areas in the leaf surface of the treated ferns increased with time, and with the increase in the total amount of metal ( $\mu \mathrm{g} / \mathrm{g} \mathrm{DW})$ accumulated in such organs (Figure 1). This behavior was most pronounced from day 5 of metal exposure onwards in agreement with a related study by Wolff et al. [17]. Additionally, the necrotized areas presented dark brown pigmentation from the edge of the leaf toward the middle. At day 10, clear images of an opaque deposition along the middle lamellae of the plant biomass were detected, in conjunction with an entire leaf opening. Moreover, marked tissue necrosis in those areas of greatest contact with the Cd-contaminated water was spotted via stereomicroscopic analysis. This pattern could be associated with a reduced stomatal opening and a concomitant lowered rate of photosynthesis, and also with a diminished nutrient absorption and transportation $[13,17]$. On the contrary, the Cd-unexposed control plants showed no apparent changes in leaf phenotype after 10 days with respect to the initial condition (Figure 2), suggesting a proper conservation of its initial physiological state.

According to our observations, S. biloba specimens exposed to Cd presented morphological changes proportional to the concentration of metal bioaccumulated in the leaves. Therefore, these results support the potential use of this aquatic fern as ecological indicators of $\mathrm{Cd}$ presence in aquatic environments since phenotypic changes in plant leaves induced by the metal were clearly visible and easily quantified. 


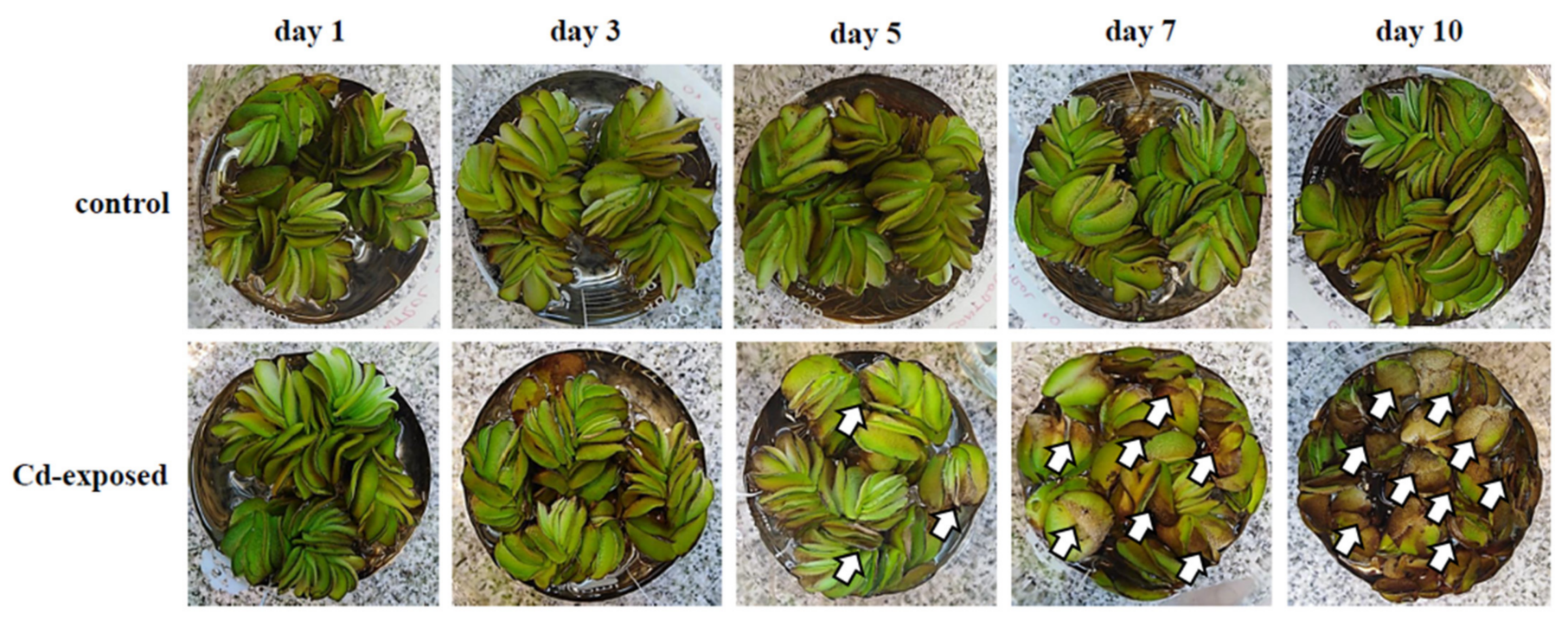

Figure 2. Representative photographs showing phenotypic alterations observed in S. biloba leaves during 10-day exposure to water contaminated with $100 \mu \mathrm{M}$ Cd compared to the leaves of control plants. Arrows indicate some of the representative changes in leaves (chlorosis and signs of necrosis) described in Section 3.2.

\subsection{Cd Phytotoxicity in S. biloba \\ 3.3.1. Photosynthetic Pigments}

The variation in the content of the photosynthetic pigments (i.e., chlorophylls and carotenoids) is frequently used to assess heavy metal toxicity in plants, including aquatic macrophytes $[12,13,15]$. Chlorophylls are the main chloroplast pigments responsible for collecting solar radiation during the photosynthetic processes [40]. Therefore, it is important to record changes in both major types of green pigment, chlorophyll $a(\mathrm{chl} a)$ and chlorophyll $b(\mathrm{chl} b)$. This is due to the fact that different metals could affect each chlorophyll component at different levels [12-15]. On the other hand, carotenoids are essential to photosynthesis acting as secondary pigments, pro-vitamin factors, and to eliminate reactive oxygen species (ROS) in the damaged tissues [40]. Considering that the content of photosynthetic pigments in floating fronds of Salvinia sp. is at least two to three times higher than that of the submerged roots [41,42], we restricted the evaluation of chl $a$, chl $b$, and carotenoid concentrations to the leaves.

As observed in Figure 3, chlorophylls were less affected by the metal exposure $(100 \mu \mathrm{M}$ Cd) than carotenoids. The concentration of chl $a$ in the leaves of Cd-treated plants only significantly decreased $(p<0.05)$ at days 7 and 10 of metal exposure with respect to the control group. This result is consistent with the photographs depicted in Figure 2, in which plants exposed to $\mathrm{Cd}$-contaminated water showed a marked increase in leaf chlorosis from day 7 onwards; whereas before that point the floating fronds exhibited a darker uniform green color likely related to greater chl $a$ content.

Noticeably, chl $b$ was more resistant to $\mathrm{Cd}$ accumulation in plant leaves, most likely due to a faster hydrolysis ratio of chl $a$ compared with chl $b$ when plants are under metallic stress [12,13]. Chl $b$ is found in light harvesting complexes, playing a critical role in the absorption of light at $425-475 \mathrm{~nm}$, where chl $a$ absorbs significantly less than chl $b$ [40]. Despite this, no plant showed reduction in biomass yield compared with the control group after a 10-day Cd exposure (Figure 2).

Carotenoid concentration in Cd-treated S. biloba specimens showed a significant $(p<0.05)$ increase at day 5 , followed by a pronounced decrease at days 7 to 10 of metal exposure, in relation to the control group. Moderate concentrations of $\mathrm{Cd}$ caused an increase in carotenoids, which protects against stress, since these pigments are quenchers of $\operatorname{ROS}\left({ }^{1} \mathrm{O}_{2}\right)$ and of triplet excited states of chlorophyll [40], reducing lipid peroxidation and consequent oxidative damage. However, the increasing accumulation of $\mathrm{Cd}$ significantly accelerates the degradation of the photosynthetic pigments in S. biloba. The reduction of 
these pigments most likely relates to the increase in ROS acquired from the damage of the photosystems. The ionic imbalance caused by excessive $\mathrm{Cd}$ may affect aminolevulinic acid synthesis (precursor of chlorophyll), increasing degradation of the pigments $[15,43]$.
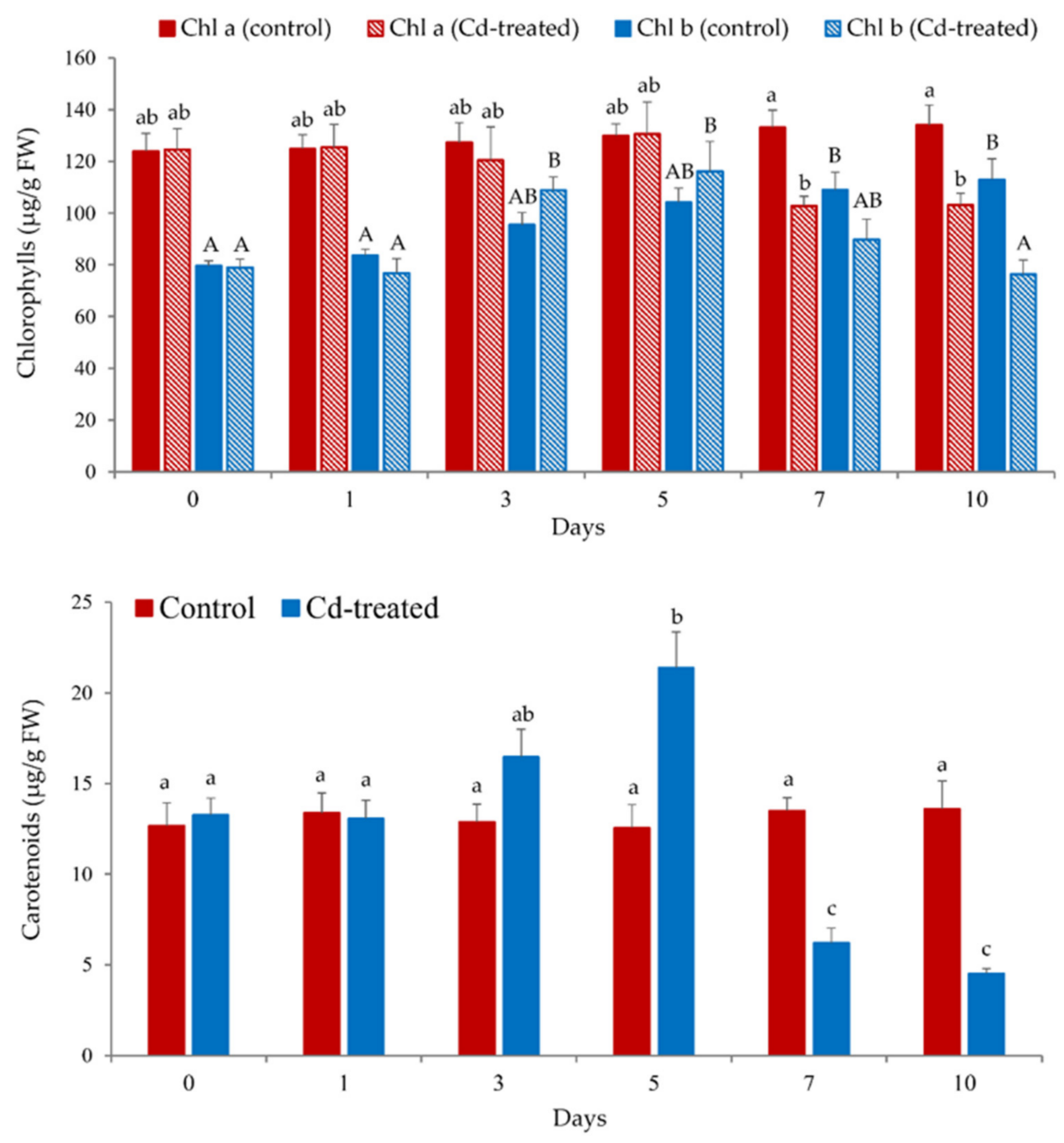

Figure 3. Photosynthetic pigment (chlorophylls, top; and carotenoids, bottom) content in S. biloba leaves during 10-day exposure to water contaminated with $100 \mu \mathrm{M} \mathrm{Cd}$. Different letters (lowercase or uppercase) represent statistically significant differences $(p<0.05)$, e.g., "a" and " $\mathrm{b}$ " are statistically different from each other but not from "ab". Data are reported as the mean value \pm standard error (S.E.) from three biological replicates $(n=3)$.

Oxidative stress is a well-known physiological effect of heavy metals in plants and other autotrophic aquatic organisms $[15,43,44]$. ROS are produced in the chloroplast, either as byproducts of $\mathrm{O}_{2}$ reduction or as a result of the presence of highly energized photopigments $[45,46]$. The observed increase in carotenoids (Figure 3) may be explained by the fact that xanthophylls and carotenes quench excess excitation energy to protect chlorophylls from oxidative damage and to stabilize the lipid bilayer of cell membranes, preventing ROS-induced lipid peroxidation $[15,17,39,44,45]$. However, metal excess in plant tissues can affect photosynthesis by a series of factors, including degradation and/or biosynthesis inhibition of chlorophylls, plastoquinone, and carotenoids; disruption of chloroplast organization; and changes in the composition of the thylakoid membrane where the photosynthetic pigments are deposited $[15,17,39,43,45,46]$. All of these processes can explain the decrease in photosynthetic pigments in S. biloba leaves from day 7 onwards, when the concentration of $\mathrm{Cd}$ in plant tissue exceeded $10.0 \mu \mathrm{g} / \mathrm{g}$ (dry basis) (Figures 1 and 3). 
In a recent study, we have investigated the effect of different metals $(\mathrm{Cd}, \mathrm{Cu}, \mathrm{Pb}$, and $\mathrm{Zn}$ ) on the photosynthetic activity of S. biloba. However, no changes in chlorophyll and carotenoid levels in the leaves of $S$. biloba were observed after $48 \mathrm{~h}$ of plant exposure to 50 and $100 \mu \mathrm{M} \mathrm{Cd}$ [12]. Thus, the results of this work highlight the significance of carrying out longer metal exposure trials to identify additional physiological changes that could operate as biomarkers of metal toxicity and as a tool for the selection of macrophytes for biomonitoring and remediation purposes.

\subsubsection{Flavonoid Content}

The concentration of flavonoids in floating fronds of $S$. biloba exposed during 10 days to water containing $100 \mu \mathrm{M} \mathrm{Cd}$ was significantly $(p<0.05)$ impacted from the third day of metal challenge onwards (Figure 4).

\section{Leaves}

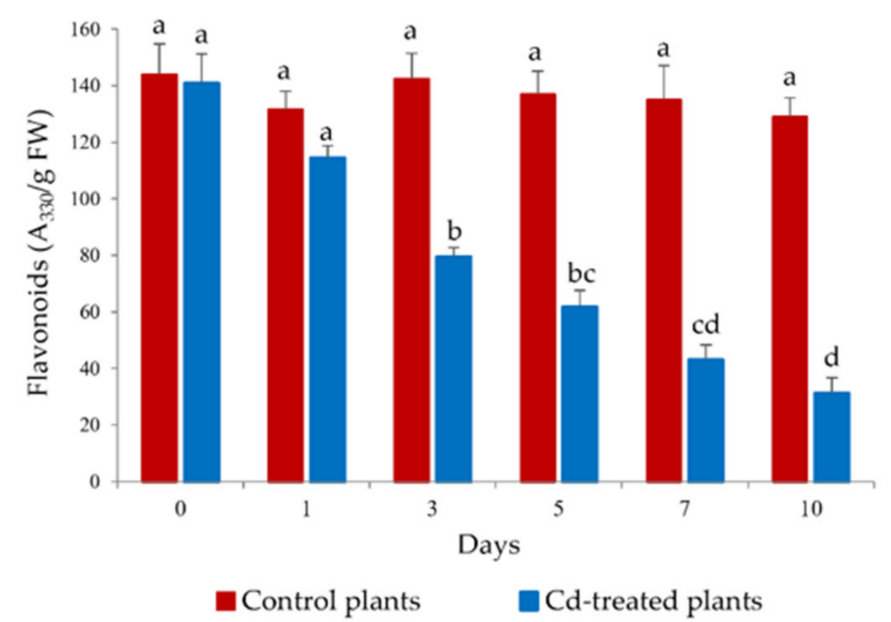

Roots

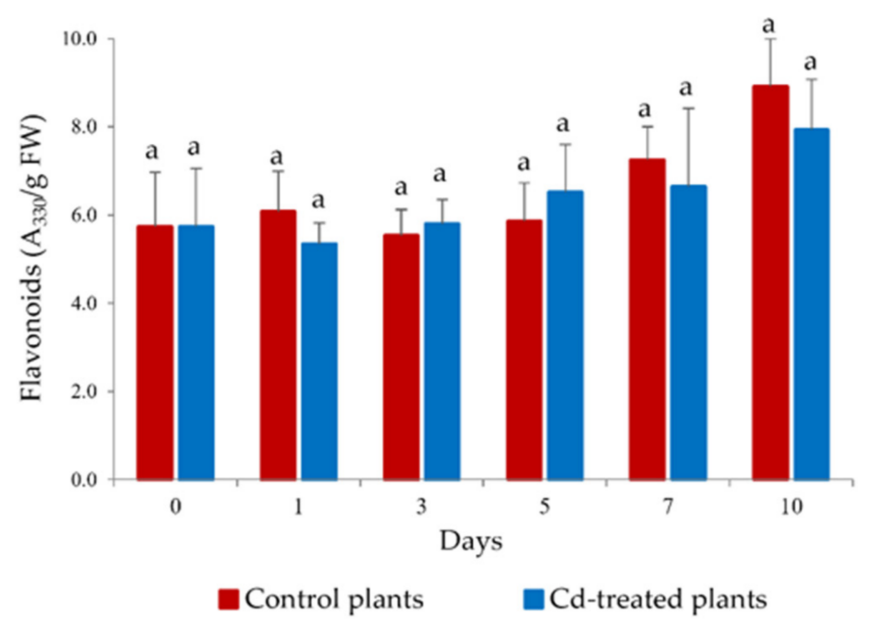

Figure 4. Flavonoid content in S. biloba leaves (left) and roots (right) during 10-day exposure to water contaminated with $100 \mu \mathrm{M}$ Cd. Different letters represent statistically significant differences $(p<0.05)$, e.g., " $c$ " is statistically different from "b" and "d", but not from "bc" or "cd". Data are reported as the mean value \pm standard error (S.E.) from three biological replicates $(n=3)$.

Phenolic compounds are essential for the plant defense against stress caused by both biotic and abiotic agents [45]. In fact, flavonoids have been reported to be involved in metal tolerance for several Salvinia species, acting as metal ion-chelating agents and preventing the generation of metal-induced ROS. For example, Bizzo et al. [15] reported an increase in the amount of total phenolic compounds in Salvinia auriculata exposed for $48 \mathrm{~h}$ to 0.01 , $0.1,1.0$, and $10 \mathrm{mM} \mathrm{Cu}(\mathrm{II})$. More recently, Prado et al. [14] observed an increase in the total amount of soluble thiols in leaves of Salvinia rotundifolia and S. minima after 7-day treatment with water contaminated with $20 \mathrm{mg} / \mathrm{L} \mathrm{Cr}(\mathrm{VI})$ (i.e., $\sim 385 \mu \mathrm{M}$ ).

In the present study, no increase in flavonoid content in S. biloba leaves was detected during the first $24 \mathrm{~h}$ of metal exposure. This result is in agreement with our previous report [12], possibly because the amount of $\mathrm{Cd}$ accumulated in the plant after this period was not detrimental at the oxidative level. However, prolonged exposure to $\mathrm{Cd}$ and its increasing accumulation in the leaves led to a significant decrease in the amount of flavonoids $(p<0.05)$ from day 3 onwards, suggesting that leaves of Cd-exposed S. biloba accumulated a metal concentration that was harmful to cell homeostasis and caused metabolic breakdown. Inversely, the concentration of flavonoids in S. biloba roots of control and Cd-treated specimens did not change during the entire trial (Figure 4).

It is worth noting that root flavonoids play significant roles in protecting the plants against pests and diseases, regulating root growth and functions, influencing different aspects of nitrogen cycle, and exerting allelopathic growth effects [47]. In addition, Fini et al. [48] suggested that in plants subjected to severe/prolonged stress, the very 
conditions that lead to the inactivation of antioxidant enzymes can also upregulate the biosynthesis of antioxidant flavonoids as a secondary ROS-scavenging system.

Different studies have been conducted in order to understand the molecular basis of the response of Salvinia sp. when exposed to metals. For example, Estrella-Gómez et al. [33] demonstrated the relationship between $\mathrm{Pb}$ accumulation and the activation of chelation and metal sequestration mechanisms mediated by phytochelatins in roots of S. minima. Moreover, these authors also analyzed the connection between $\mathrm{Pb}$ accumulation and changes in glutathione (GSH) levels in S. minima roots, suggesting that an increase in GSH biosynthesis may play an important role in protecting plant organs from the oxidative damage caused by $\mathrm{Pb}$ [49]. More recently, Leal-Alvarado et al. [50] analyzed the expression levels of genes coding for ATP-dependent tonoplast transporters (ABC transporters) involved in S. minima roots tolerance to $\mathrm{Pb}$. The authors found a sharp increase in the expression of the above-mentioned genes in S. minima exposed to $40 \mu \mathrm{M} \mathrm{Pb}$ for $24 \mathrm{~h}$, suggesting their participation in the control of root cell homeostasis. Although these data were the first attempt at understanding the molecular basis of S. minima tolerance to heavy metals, it is expected that other aquatic ferns belonging to the Salvinia genus share similar mechanisms to counteract the imbalance caused by toxic metal accumulation. Therefore, the reaction of $S$. biloba against $\mathrm{Cd}$ stress is expected to be controlled by a complex and highly interrelated network of molecular and physiological approaches that help to counteract metal phytotoxicity [51].

\subsubsection{Soluble Carbohydrates}

In general, a decreasing tendency in the content of soluble carbohydrates was observed in both leaves and roots of S. biloba after 10 days of exposure to $100 \mu \mathrm{M} \mathrm{Cd}$ (Figure 5). However, after $24 \mathrm{~h}$ into the experiment, only the leaves showed a significant decrease in the amount of soluble sugars in relation to the control.

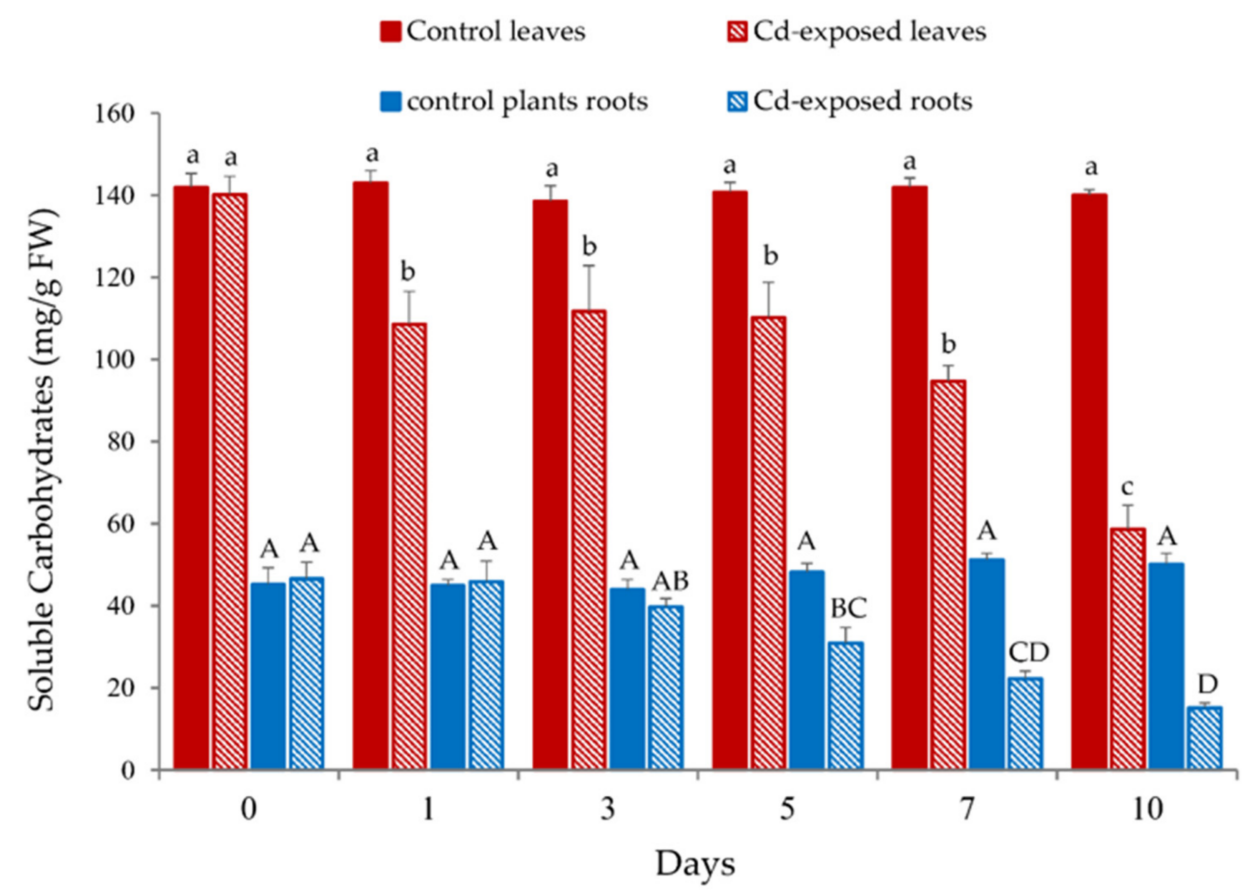

Figure 5. Soluble carbohydrate content in S. biloba leaves and roots during 10-day exposure to water contaminated with $100 \mu \mathrm{M}$ Cd. Different letters (lowercase or uppercase) represent statistically significant differences $(p<0.05)$, e.g., " $\mathrm{A}$ " and " $\mathrm{B}$ " are statistically different from each other but not from " $A B$ ". Data are reported as the mean value \pm standard error (S.E.) from three biological replicates $(n=3)$. 
In contrast, the content of soluble carbohydrates in the roots did not significantly $(p<0.05)$ decrease until the fifth day of the experiment (Figure 5). In addition to the damage of root cells, the increased bioaccumulation of $\mathrm{Cd}$ can induce the mobilization of sugar molecules where they are required to preserve the osmotic homeostasis of the root cells. Carbohydrate compounds not only act as structural cellular constituents of the cell walls, but also as intracellular signaling molecules involved in the regulation of metabolic processes associated with ATP production and cell energy management [52].

\subsection{Further Analysis-Cd Bioaccumulation vs. Physiological Parameters}

As displayed in Figure 6, the accumulation of $\mathrm{Cd}$ in the plant tissue of S. biloba influenced the assessed physiological parameters to different extents. At the end of the experiment, when maximum $\mathrm{Cd}$ bioaccumulation was registered, the parameters that exhibited greater discrepancy in relation to control were flavonoids (leaves) > carbohydrates (roots) $>$ carotenoids $>$ carbohydrates (leaves) $>$ chlorophylls $>$ flavonoids (roots) At top $\mathrm{Cd}$ concentrations in both plant organs, the reduction of flavonoids was greater in leaves $(23.5 \%$ of control) than in roots $(89.0 \%$ of control), whereas the carbohydrate decrease was higher in roots $(30.2 \%$ of control) than in the leaves (41.9\% of control). The spike in carotenoid contents when Cd levels in leaves were $5 \mu \mathrm{g} / \mathrm{g}$ (day 5 of the experiment, Figure 3), highlights the relevance of the results discussed in Section 3.3.1., i.e., the production of carotenoids as a response to the Cd-induced oxidative stress.

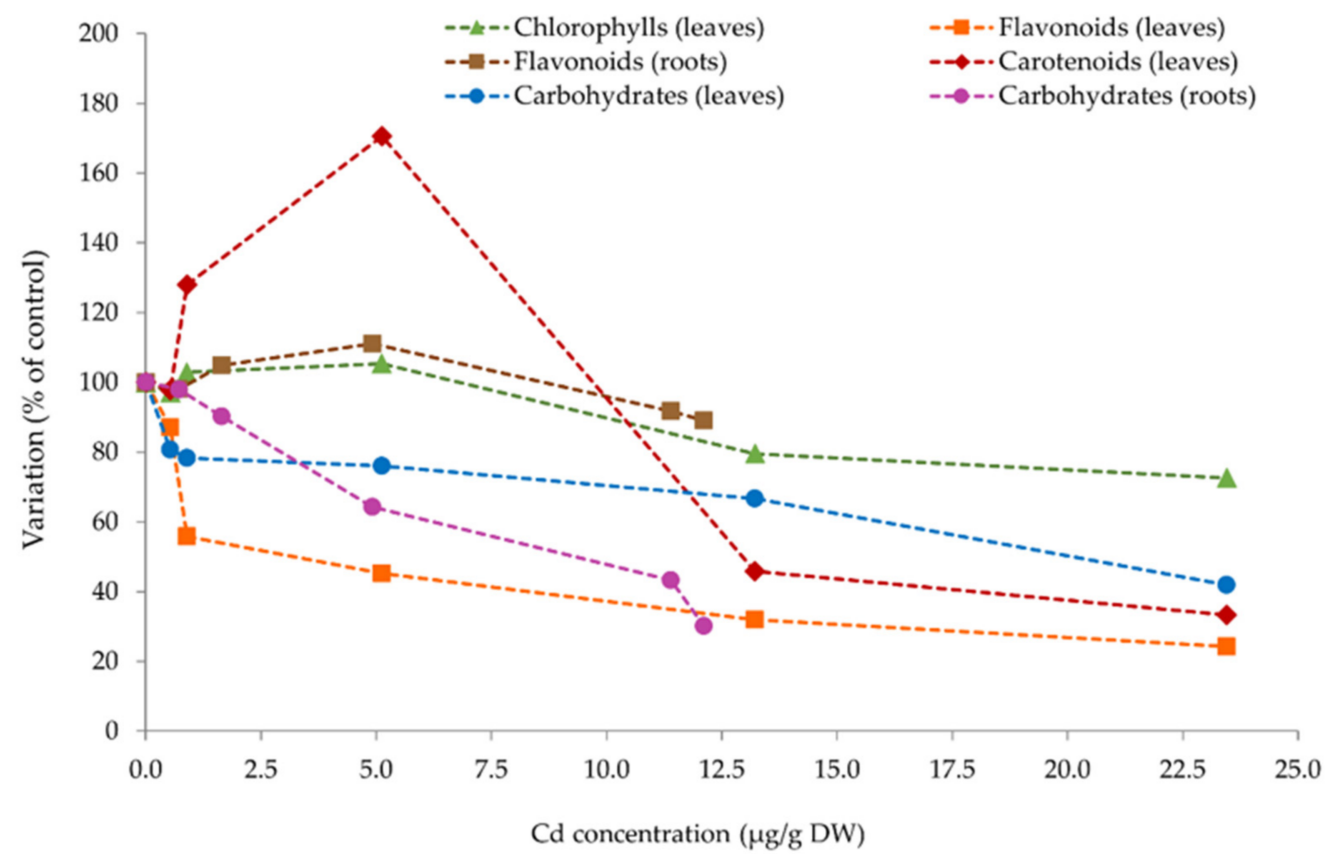

Figure 6. Variation of the assessed physiological parameters in relation to $\mathrm{Cd}$ bioaccumulation over time in the leaves and roots of S. biloba. The parameters chlorophylls (leaves), carotenoids (leaves), flavonoids (roots and leaves), and carbohydrates (roots and leaves) are presented as percentages of those obtained in the control plants. Data are reported as the mean value from three biological replicates $(n=3)$.

The correlations depicted on Figure 7 further emphasize the relationship between $\mathrm{Cd}$ exposure time, its bioaccumulation in the roots and leaves of S. biloba, and the effect in the assessed physiological parameters. As expected, significant positive correlations were found between the experiment time and $\mathrm{Cd}$ concentrations in the roots and leaves (also positively correlated between each other). Conversely, both parameters showed significant negative correlations with the concentrations of soluble carbohydrates (roots and leaves), chlorophyll $a$, carotenoids, and flavonoids (leaves). These relationships are aligned with the 
results presented in the sections above and underline our discussion about the detrimental impact of $\mathrm{Cd}$ in $\mathrm{S}$. biloba over time.

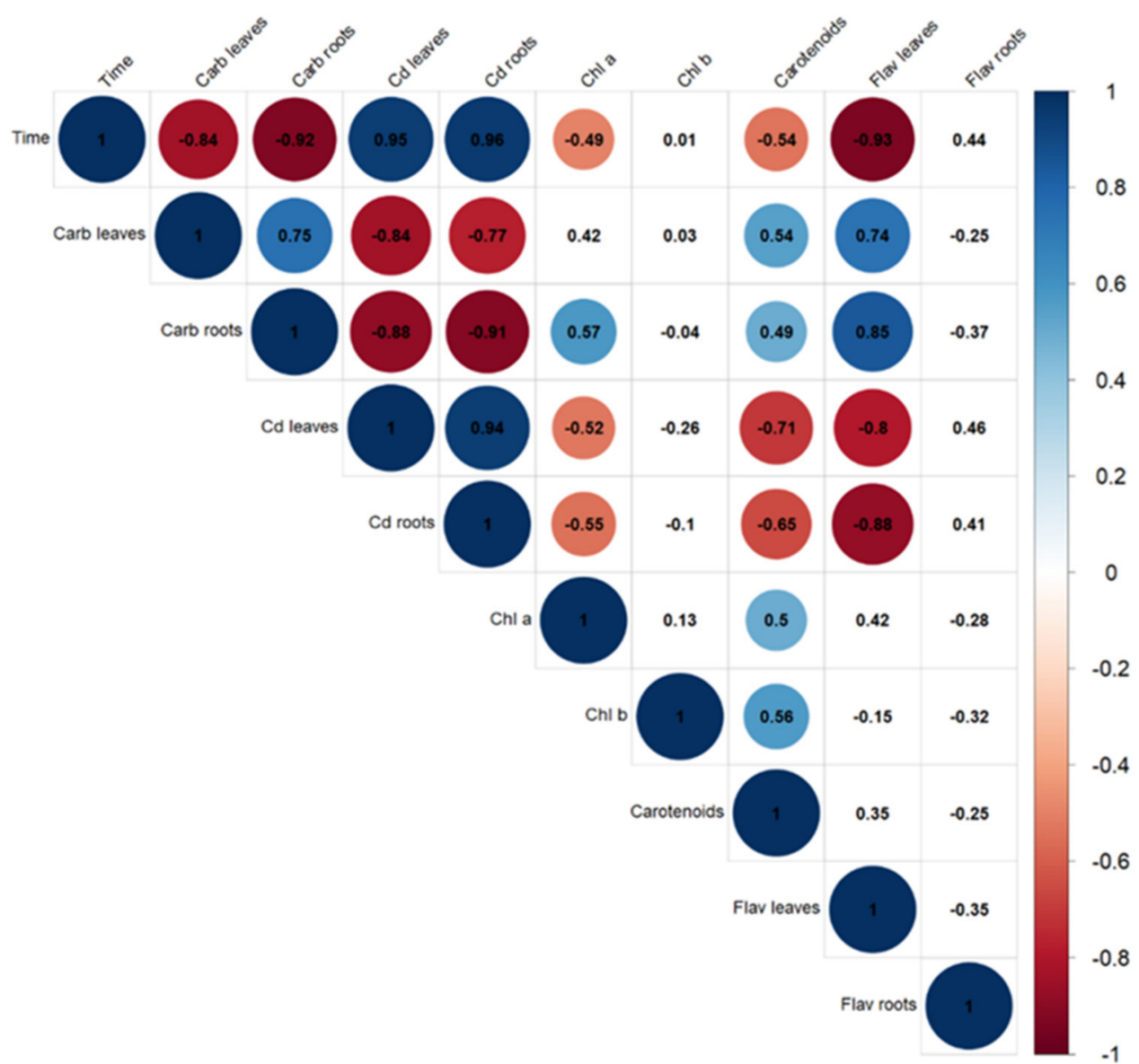

Figure 7. Pearson correlation coefficients between the assessed parameters. Correlations are significant at $p<0.05$, except on uncolored cells. Colored cells denote a positive or negative correlation between parameters as per the heatmap, i.e., darker blue cells indicate a strong positive correlation (towards +1 ), while darker red cells represent strong negative correlations (towards -1 ). In addition, the specific correlation coefficients between parameters are presented in the corresponding cells. For instance, there is a strong negative correlation (dark red, -0.91) between soluble carbohydrate contents in the roots and $\mathrm{Cd}$ concentration in the roots.

\section{Conclusions}

We have assessed the effect of $\mathrm{Cd}$ in naturally occurring S. biloba macrophytes growing in wetlands of the Middle Paraná River (Argentina). The accumulation of Cd in plant tissue induced evident visual alterations in plant leaves during 10-day metal exposure. Additionally, some of the assessed physiological parameters in S. biloba roots and leaves were more sensitive than others to the harmful effects of $\mathrm{Cd}$ bioaccumulation. Flavonoids in S. biloba leaves were the most affected parameter. On the other hand, chlorophyll levels were less impacted by $\mathrm{Cd}$ damage, while carotenoids showed a different time-dependent response. In addition, a gradual decrease in the content of soluble carbohydrates in both organs was observed over time. Therefore, the presented results demonstrate that $S$. biloba displays dissimilar physiological responses in plant roots and leaves to counteract the metal phytotoxicity. Additionally, the presented results highlight the significance to perform long-term metal exposure trials to identify additional physiological damage, thus becoming an important tool for the selection of tolerant macrophytes for biomonitoring purposes. Future research should explore a wider range of elements and their corresponding con- 
centrations, to further inform about the potential use of this locally available species as a metal-pollution bioindicator.

Author Contributions: Conceptualization, L.A.B.N., L.M.S. and L.M.P.; methodology, W.G.L.O. and J.E.; formal analysis, J.E., L.A.B.N. and L.M.P.; investigation, W.G.L.O. and J.E.; writing-original draft preparation, L.A.B.N. and L.M.P.; writing-review and editing, L.A.B.N. and L.M.P.; supervision, L.M.S. and L.M.P.; project administration, L.M.S. and L.M.P.; funding acquisition, L.A.B.N., L.M.S. and L.M.P. All authors have read and agreed to the published version of the manuscript.

Funding: This research was funded by Agencia Nacional de Promoción Científica y Tecnológica (ANPCyT, Ministerio de Ciencia, Tecnología e Innovación, Argentina) and the Pontifical Catholic University of Argentina (UCA), grant number PICTO-2017-0060.

Institutional Review Board Statement: Not applicable.

Informed Consent Statement: Not applicable.

Acknowledgments: The authors want to thank Daniela Bergara (Fac. de Química e Ingeniería del Rosario, UCA-Rosario) for her technical advice. We also want to thank Luisina Torrá (Mat. 1132, Association of Translators of the Province of Santa Fe, 2nd District) for her technical assistance during language proofreading.

Conflicts of Interest: The authors declare no conflict of interest. The funders had no role in the design of the study; in the collection, analyses, or interpretation of data; in the writing of the manuscript, or in the decision to publish the results.

\section{References}

1. Lesiv, M.S.; Polishchuk, A.I.; Antonyak, H.L. Aquatic macrophytes: Ecological features and functions. Biol. Stud. 2020, 14, 79-94. [CrossRef]

2. Rejmánková, E. The Role of Macrophytes in Wetland Ecosystems. J. Ecol. Field Biol. 2011, 34, 333-345. [CrossRef]

3. Bonanno, G.; Borg, J.A.; Di Martino, V. Levels of Heavy Metals in Wetland and Marine Vascular Plants and Their Biomonitoring Potential: A Comparative Assessment. Sci. Total Environ. 2017, 576, 796-806. [CrossRef] [PubMed]

4. Alonso, X.; Hadad, H.R.; Córdoba, C.; Polla, W.; Reyes, M.S.; Fernández, V.; Granados, I.; Marino, L.; Villalba, A. Macrophytes as Potential Biomonitors in Peri-Urban Wetlands of the Middle Parana River (Argentina). Environ. Sci. Pollut. Res. 2018, 25, 312-323. [CrossRef] [PubMed]

5. Fawzy, M.A.; Badr, N.; El-Khatib, A.; Abo-El-Kassem, A. Heavy Metal Biomonitoring and Phytoremediation Potentialities of Aquatic Macrophytes in River Nile. Environ. Monit. Assess. 2012, 184, 1753-1771. [CrossRef] [PubMed]

6. Freitas, F.; Battirola, L.D.; de Andrade, R.L.T. Adsorption of $\mathrm{Cu}^{2+}$ and $\mathrm{Pb}^{2+}$ Ions by Pontederia rotundifolia (L.f.) (Pontederiaceae) and Salvinia biloba Raddi (Salviniaceae) biomass. Water Air Soil Pollut. 2018, 229, 349. [CrossRef]

7. Dixit, R.; Wasiullah, E.; Malaviya, D.; Pandiyan, K.; Singh, U.B.; Sahu, A.; Shukla, R.; Singh, B.P.; Rai, J.P.; Sharma, P.K.; et al. Bioremediation of Heavy Metals from Soil and Aquatic Environment: An Overview of Principles and Criteria of Fundamental Processes. Sustainability 2015, 7, 2189-2212. [CrossRef]

8. Sharma, P.; Pandey, S. Status of Phytoremediation in World Scenario. Int. J. Environ. Bioremediat. Biodegrad. 2014, 2, $178-191$. [CrossRef]

9. Dhir, B. Potential of Biological Materials for Removing Heavy Metals from Wastewater. Environ. Sci. Pollut. Res. Int. 2014, 21, 1614-1627. [CrossRef] [PubMed]

10. Ali, H.; Khan, E.; Sajad, M.A. Phytoremediation of Heavy Metals-Concepts and Applications. Chemosphere 2013, 91, 869-881. [CrossRef] [PubMed]

11. Rai, P.K. Heavy Metal Phytoremediation from Aquatic Ecosystems with Special Reference to Macrophytes. Crit. Rev. Environ. Sci. Technol. 2009, 39, 697-753. [CrossRef]

12. Emiliani, J.; Llatance Oyarce, W.G.; Bergara, C.D.; Salvatierra, L.M.; Novo, L.A.B.; Pérez, L.M. Variations in the Phytoremediation Efficiency of Metal-Polluted Water with Salvinia biloba: Prospects and Toxicological Impacts. Water 2020, 12, 1737. [CrossRef]

13. Castillo Loría, K.; Emiliani, J.; Herrero, M.S.; Bergara, C.D.; Salvatierra, L.M.; Pérez, L.M. Effect of Daily Exposure to Pb-Contaminated Water into Salvinia biloba Physiology and Phytoremediation Performance. Aquat. Toxicol. 2019, 210, 158-166. [CrossRef]

14. Prado, C.; Ponce, S.C.; Pagano, E.; Prado, F.E.; Rosa, M. Differential Physiological Responses of Two Salvinia Species to Hexavalent Chromium at a Glance. Aquat. Toxicol. 2016, 175, 213-221. [CrossRef] [PubMed]

15. Bizzo, A.L.; Intorne, A.C.; Gomes, P.H.; Susuki, M.S.; Esteves, B.D. Short-Term Physiological Responses to Copper Stress in Salvinia auriculata Aubl. Acta Limnol. Bras. 2014, 26, 268-277. [CrossRef]

16. Dhir, B.; Sharmila, P.; Pardha-Saradhi, P.; Sharma, P.; Kumar, R.; Mehta, D. Heavy Metal Induced Physiological Alterations in Salvinia natans. Ecotoxicol. Environ. Saf. 2011, 74, 1678-1684. [CrossRef] 
17. Wolff, G.; Pereira, G.C.; Castro, E.M.; Louzada, J.; Coelho, F.F. The Use of Salvinia auriculata as a Bioindicator in Aquatic Ecosystems: Biomass and Structure Dependent on the Cadmium Concentration. Braz. J. Biol. 2012, 72, 71-77. [CrossRef]

18. Freitas, F.; Lunardi, S.; Souza, L.B.; von der Osten, J.S.C.; Arruda, R.; Andrade, R.L.T.; Battirola, L.D. Accumulation of Copper by the Aquatic Macrophyte Salvinia biloba Raddi (Salviniaceae). Braz. J. Biol. 2018, 78, 133-139. [CrossRef] [PubMed]

19. Tello Zevallos, W.; Salvatierra, L.M.; Loureiro, D.B.; Morató, J.; Pérez, L.M. Evaluation of the Autochthonous Free-Floating Macrophyte Salvinia biloba Raddi for Use in the Phytoremediation of Water Contaminated. Desalin. Water Treat. 2018, 103, 282-289. [CrossRef]

20. Ferreira, F.A.; Mormul, R.P.; Thomaz, S.M.; Pott, A.; Pott, V.J. Macrophytes in the Upper Paraná River floodplain: Checklist and Comparison with Other Large South American Wetlands. Rev. Biol. Trop. 2011, 59, 541-556. [PubMed]

21. Guerrero, E.L.; Agnolin, F.L.; Benedictto, M.; Gambeta, D.; Suazo Lara, F.A.; Derguy, M.R.; Apodaca, M.J. Vascular Plant Species of the Floating Vegetation Rafts from the Río de la Plata (Argentina). Rodriguésia 2018, 69, 1965-1972. [CrossRef]

22. Briffa, J.; Sinagra, E.; Blundell, R. Heavy metal pollution in the environment and their toxicological effects on humans. Heliyon 2020, 6, e04691. [CrossRef] [PubMed]

23. Rahimzadeh, M.R.; Kazemi, S.; Moghadamnia, A.A. Cadmium Toxicity and Treatment: An Update. Casp. J. Intern. Med. 2017, 8, 135-145. [CrossRef]

24. Qu, R.J.; Wang, X.H.; Feng, M.B.; Li, Y.; Liu, H.X.; Wang, L.S.; Wang, Z.Y. The Toxicity of Cadmium to Three Aquatic Organisms (Photobacterium phosphoreum, Daphnia magna and Carassius auratus) under Different pH Levels. Ecotoxicol. Environ. Saf. 2013, 95, 83-90. [CrossRef] [PubMed]

25. Zaki, M.S.; Zakaria, A.; Eissa, I.A.; Eldeen, A.I. Effect of Cadmium Toxicity on Vertebrates. Electron. Physician 2016, 8, 1964-1965. [CrossRef]

26. Hayat, M.T.; Nauman, M.; Nazir, N.; Ali, S.; Bangash, N. Environmental Hazards of Cadmium: Past, Present, and future. In Cadmium Toxicity and Tolerance in Plants: Agronomic, Genetic, Molecular and Omic Approaches, 1st ed.; Hasanuzzaman, M., Prasad, M.N.V., Fujita, M., Eds.; Academic Press: Cambridge, MA, USA, 2019; pp. 163-183. [CrossRef]

27. WHO. Chemical Safety-Activity Report; World Health Organization: Geneva, Switzerland, 2017.

28. Lichtenthaler, H.K.; Wellburn, A.R. Determinations of Total Carotenoids and Chlorophylls A and B of Leaf Extracts in Different Solvents. Biochem. Soc. Trans. 1983, 11, 591-592. [CrossRef]

29. Robyt, I.F.; White, J.B. Biochemical Techniques: Theory and Practice, 1st ed.; Brooks and Cole Publishing: Monterey, CA, USA, 1987; $407 \mathrm{p}$.

30. R Core Team. R: A Language and Environment for Statistical Computing; R Foundation for Statistical Computing: Vienna, Austria, 2021.

31. Sánchez-Galván, G.; Monroy, O.; Gómez, J.; Olguín, E.J. Assessment of the Hyperaccumulating Lead Capacity of Salvinia minima Using Bioadsorption and Intracellular Accumulation Factors. Water Air Soil Pollut. 2008, 194, 77-90. [CrossRef]

32. Olguín, E.J.; Sánchez-Galván, G.; Pérez-Pérez, T.; Pérez-Orozco, A. Surface Adsorption, Intracellular Accumulation and Compartmentalization of Lead in Batch-Operated Lagoons with Salvinia minima as Affected by Environmental Conditions, EDTA and Nutrients. J. Ind. Microbiol. Biotechnol. 2005, 32, 577-586. [CrossRef] [PubMed]

33. Estrella-Gómez, N.; Mendoza-Cózatl, D.; Romero-Sánchez, R.; Gonzáles-Mendoza, D.; Zapata-Pérez, O.; Martínez-Hernández, A.; Santamaría, J.M. The Pb-Hyperaccumulator Aquatic Fern Salvinia minima Baker, Responds to Pb ${ }^{2+}$ by Increasing Phytochelatins via Changes in SmPCS Expression and in Phytochelatin Synthase Activity. Aquat. Toxicol. 2009, 91, 320-328. [CrossRef] [PubMed]

34. Schor-Fumbarov, T.; Goldsbrough, P.; Adam, Z.; Tel-Or, E. Characterization and Expression of a Metallothionein Gene in the Aquatic Fern Azolla filiculoides Under Heavy Metal Stress. Planta 2005, 223, 69-76. [CrossRef] [PubMed]

35. Cobbett, C.S. Phytochelatins and Their Roles in Heavy Metal Detoxification. Plant Physiol. 2000, 123, 825-832. [CrossRef]

36. Mendoza-Cózatl, D.; Rodríguez-Zavala, J.; Rodríguez-Enríquez, S.; Mendoza-Hernandez, G.; Briones-Gallardo, G.; MorenoSánchez, R. Phytochelatin-Cadmium—Sulfide High-Molecular-Mass Complexes of Euglena gracilis. FEBS J. 2006, 273, 5703-5713. [CrossRef] [PubMed]

37. Phetsombat, S.; Kruatrachue, M.; Pokethitiyook, P.; Upatham, S. Toxicity and Bioaccumulation of Cadmium and Lead in Salvinia cucullata. J. Environ Biol. 2006, 27, 645-652.

38. Tello Zevallos, W.; Loureiro, D.B.; Reeves, M.C.; Yujnovsky, F.; Salvatierra, L.M.; Pérez, L.M. Biorremediación de Aguas Contaminadas con Metales Pesados Empleando Macrófitas Autóctonas de Flotación Libre. In IV Simposio Argentino de Procesos Biotecnológicos: Libro de Resúmenes, Proceeding of the 4th Simposio Argentino de Procesos Biotecnológicos (SAPROBIO 2016), Buenos Aires, Argentina, 1-2 December 2016; Carbajal, M.L., Rojas, N.L., Grasselli, M., Eds.; (Universidad Nacional de Quilmes), Bernal: Buenos Aires, Argentina, 2017; Abstract Number: S4.22; pp. 242-243; ISBN 978-987-558-428-0.

39. Williams, L.E.; Pittman, J.K.; Hall, J.L. Emerging Mechanisms for Heavy Metal Transport in Plants. Biochim. Biophys. Acta 2000, 1465, 104-126. [CrossRef]

40. Gomes, S.M.S.; De Lima, V.L.A.; De Souza, A.P.; Do Nascimento, J.J.V.R.; Do Nascimento, E.S. Chloroplast Pigments as Indicators of Lead Stress. Eng. Agríc. 2014, 34, 877-884. [CrossRef]

41. Babenko, L.M.; Shcherbatiuk, M.M.; Polishchuk, O.V.; Kosakivska, I.V. Structural-Functional Peculiarities of Water Fern Salvinia natans (L.) All. Biol. Stud. 2016, 10, 149-162. [CrossRef]

42. Kosakivska, I.V.; Shcherbatiuk, M.M.; Babenko, L.M.; Polishchuk, O.V. Characteristics of Photosynthetic Apparatus of Aquatic Fern Salvinia natans Floating and Submerged Fronds. Adv. Biol. Earth Sci. 2018, 3, 13-26. 
43. Fryzova, R.; Pohanka, M.; Martinkova, P.; Cihlarova, H.; Brtnicky, M.; Hladky, J.; Kynicky, J. Oxidative Stress and Heavy Metals in Plants. Rev. Environ. Contam. Toxicol. 2018, 245, 129-156. [CrossRef]

44. Carralero Bon, I.; Salvatierra, L.M.; Lario, L.D.; Morató, J.; Pérez, L.M. Prospects in Cadmium-Contaminated Water Management Using Free-Living Cyanobacteria (Oscillatoria sp.). Water 2021, 13, 542. [CrossRef]

45. Ramel, F.; Mialoundama, A.S.; Havaux, M. Nomenzymic Carotenoid Oxidation and Photooxidative Stress Signalling in Plants. J. Exp. Bot. 2013, 64, 799-805. [CrossRef]

46. Munné-Bosch, S.; Queval, G.; Foyer, C.H. The Impact of Global Change Factors on Redox Signaling Underpinning Stress Tolerance. Plant Physiol. 2013, 161, 5-19. [CrossRef] [PubMed]

47. Caretto, S.; Linsalata, V.; Colella, G.; Lattanzio, V. Carbon Fluxes Between Primary Metabolism and Phenolic Pathway in Plant Tissues Under Stress. Int. J. Mol. Sci. 2015, 16, 26378-26394. [CrossRef] [PubMed]

48. Fini, A.; Brunetti, C.; Di Ferdinando, M.; Ferrini, F.; Tattini, M. Stress-Induced Flavonoid Biosynthesis and the Antioxidant Machinery of Plants. Plant Signal. Behav. 2011, 6, 709-711. [CrossRef]

49. Estrella-Gómez, N.E.; Sauri-Duch, E.; Zapata-Pérez, O.; Santamaría, J.M. Glutathione Plays a Role in Protecting Leaves of Salvinia minima from $\mathrm{Pb}^{2+}$ Damage Associated with Changes in the Expression of SmGS Genes an Increased Activity of GS. Environ. Exp. Bot. 2012, 75, 188-194. [CrossRef]

50. Leal-Alvarado, D.A.; Estrella-Maldonado, H.; Sáenz-Carbonell, L.; Ramírez-Prado, J.H.; Zapata-Pérez, O.; Santamaría, J.M. Genes Coding for Transporters Showed a Rapid and Sharp Increase in Their Expression in Response to Lead, in the Aquatic Fern (Salvinia minima Baker). Ecotoxicol. Environ. Saf. 2018, 147, 1056-1064. [CrossRef] [PubMed]

51. Singh, S.; Parihar, P.; Singh, R.; Singh, V.P.; Prasad, S.M. Heavy Metal Tolerance in Plants: Role of Transcriptomics, Proteomics, Metabolomics, and Ionomics. Front. Plant Sci. 2016, 6, 1143. [CrossRef] [PubMed]

52. Rosa, M.; Prado, C.; Podazza, G.; Interdonato, R.; González, A.; Prado, F. Soluble Sugars-Metabolism, Sensing and Abiotic Stress. Plant Signal. Behav. 2009, 4, 388-393. [CrossRef] [PubMed] 